\title{
Presenilin-2 Mutation Causes Early Amyloid Accumulation and Memory Impairment in a Transgenic Mouse Model of Alzheimer's Disease
}

\author{
Toshihiko Toda, ${ }^{1,2}$ Yoshihiro Noda, ${ }^{1}$ Genzo Ito, ${ }^{3}$ Masahiro Maeda, ${ }^{3}$ and Takahiko Shimizu ${ }^{1}$ \\ ${ }^{1}$ Molecular Gerontology, Tokyo Metropolitan Institute of Gerontology, 35-2 Sakae-Cho, Itabashi-Ku, Tokyo 173-0015, Japan \\ ${ }^{2}$ JAC Co, Ltd, 1-2-7 Higashiyama, Meguro-Ku, Tokyo 153-0043, Japan \\ ${ }^{3}$ Immuno-Biological Laboratories Co, Ltd., 1091-1 Naka, Aza-Higashida, Fujioka-shi, Gunma 370-0831, Japan
}

Correspondence should be addressed to Takahiko Shimizu, shimizut@tmig.or.jp

Received 15 September 2010; Revised 17 November 2010; Accepted 4 December 2010

Academic Editor: Monica Fedele

Copyright (C) 2011 Toshihiko Toda et al. This is an open access article distributed under the Creative Commons Attribution License, which permits unrestricted use, distribution, and reproduction in any medium, provided the original work is properly cited.

In order to clarify the pathophysiological role of presenilin-2 (PS2) carrying the Volga German Kindred mutation (N141I) in a conventional mouse model of Alzheimer's disease (AD) expressing amyloid precursor protein (APP) with the Swedish mutation (Tg2576 line), we generated a double transgenic mouse (PS2Tg2576) by crossbreeding the PS2 mutant with Tg2576 mice. Here, we demonstrate that the PS2 mutation induced the early deposition of amyloid $\beta$-protein $(\mathrm{A} \beta)$ at 2-3 months of age and progressive accumulation at 4-5 months of age in the brains of the mutant mice. The PS2 mutation also accelerated learning and memory impairment associated with $\mathrm{A} \beta$ accumulation at 4-5 months of age in Tg2576 mice. These results suggest that the PS2 mutation causes early cerebral amyloid accumulation and memory dysfunction. PS2Tg2576 mice are a suitable mouse model for studying amyloid-lowering therapies.

\section{Introduction}

Alzheimer's disease $(\mathrm{AD})$ is a progressive neurodegenerative disorder involving memory dysfunction that is characterized by cerebral amyloid accumulation, which is observed as senile plaques consisting of amyloid $\beta$-proteins $(A \beta)$ ending at the $\mathrm{Ala}^{42}$ or $\mathrm{Val}^{40}$ residues ( $\mathrm{A} \beta 42$ and $\mathrm{A} \beta 40$, resp.) [1]. Although robust $A \beta$ deposition was observed in the postmortem brains of critical AD patients with hippocampal atrophy, the pathological relationship between memory impairment and amyloid pathologies remains unclear. $A \beta$ is produced from $\beta$-amyloid precursor protein (APP) by two proteases, $\beta$ - and $\gamma$-secretases $[2,3]$. Mutations in the genes for APP or two homologous genes, presenilin-1 and -2 (PS1 and PS2), which produce components of the $\gamma$-secretase complex are linked to familial Alzheimer's disease (FAD) $[4,5]$. FAD represents a small percentage (about $5 \%$ ) of $\mathrm{AD}$ cases, but the pathology of this disease arises at an unusually young age, as early as the third decade of life, and so is termed early-onset $\mathrm{AD}$.
To understand the pathophysiological relationship between amyloidosis and memory impairment in $\mathrm{AD}$ in order to develop effective therapies and preventative measures (reviews $[6,7]$ ), FAD-linked mutations in APP have been produced in mice to provide AD mouse models, such as PDAPP [8], Tg2576 [9], APP23 [10], and TgCRND8 mice [11]. These mice typically demonstrate diffuse deposition of amyloid plaques with dystrophic neurites, in addition to inflammatory responses in microgliosis and astroglioses, but no neurofibrillary tangle pathology. The Tg2576 mouse line, which expresses the prion promoter-driven human APP with the Swedish mutation (APPswe, Lys ${ }^{670}$ Asn, and Met ${ }^{671}$ Leu) has been utilized as a model for AD analyses [9]. Tg2576 mice showed impaired spatial learning and memory in the Morris water maze at 6 months of age [12], when amyloid deposition was not observed in their brain. Typical neuritic plaques appeared in $\operatorname{Tg} 2576$ mice brain at 7-8 months of age [9].

Many FAD pathologic mutations have been reported in the PS1 gene, and transgenic mouse models have been 
produced by crossbreeding with APP mutant mice to clarify the pathological role of the PS1 mutation on APP mutant mice, such as PS1Tg2576 [13]. Gordon et al. reported that the PS1 mutation accelerated AD-like pathologies with increased $\mathrm{A} \beta 42$ production through enhanced $\gamma$-secretase activity in PS1 (Met ${ }^{146} \mathrm{Leu}$ ) and Tg2576 double transgenic mice (PS1Tg2576) [13]. In contrast, the FAD-linked mutations found in the PS2 gene have been well characterized, including Asn $^{141}$ Ile (N141I, Volga German Kindred type) [14] and $\mathrm{Met}^{239} \mathrm{Val}$ (M239V, Italian FAD type) [15]. These PS2 mutations also enhance $\gamma$-secretase activity, leading to increased $\mathrm{A} \beta 42$ production [16].

In the present study, to clarify the pathophysiological role of the PS2 (N141I) mutation on amyloid formation and memory function in Tg2576 mice, we generated double transgenic mice (PS2Tg2576) by crossbreeding a PS2 mutant with Tg2576 mice. We show the early onset of AD-like phenotypes in PS2Tg2576 mice compared to Tg2576 mice.

\section{Materials and Methods}

2.1. Mice. $\operatorname{Tg} 2576$ mice (Tg(APPSWE)2576Kha), which express human $\beta$-amyloid precursor proteins (hAPP) containing the $\mathrm{K} 670 \mathrm{~N}$ and M671L mutations, which are known as the Swedish type mutation (APPswe), coupled with hamster prion promoter on a 129S6.Cg background were purchased from Taconic Laboratories [9]. PS2M1 mice, which express human presenilin-2 (PS2) proteins containing the N141I mutation on a C57BL/6JJcl background, were also used [17]. The PS2 transgene is expressed under control of a ubiquitous CAGGS promoter consisting of cytomegalovirus early enhancer coupled with chicken $\beta$-actin promoter. We crossbred a Tg2576 male mouse with PS2 female mice using in vitro fertilization and embryo transfer techniques to generate PS2Tg2576 double transgenic mice born on the same day.

The mouse genotyping was performed using the polymerase chain reaction (PCR) method. Tail tips were dissolved in $700 \mu \mathrm{L}$ of $0.05 \mathrm{~N} \mathrm{NaOH}$ for $45 \mathrm{~min}$ at $95^{\circ} \mathrm{C}$ and then suspended in $60 \mu \mathrm{L}$ of $1 \mathrm{M}$ Tris- $\mathrm{HCl}, \mathrm{pH}$ 8.0. The suspensions were centrifuged at $20,400 \times \mathrm{g}$ for $10 \mathrm{~min}$ at $4^{\circ} \mathrm{C}(\mathrm{MX}-100$, TOMY) The resultant supernatants were collected and used as DNA templates. The primers for PS2M1 (5' -CGG CTC TAG AGC CTC TGC TAA C- $3^{\prime}$ and $5^{\prime}$-CTC TGT GTA GAA GCG CAC AGA C-3') and Tg2576 (5'-CTG ACC ACT CGA CCA GGT TCT GGG T- $3^{\prime}$ and $5^{\prime}$-GTG GAT AAC CCC TCC CCC AGC CTA GAC CA-3') were used to identify each transgenic allele. PCR was performed using the following conditions: 1 cycle of $94^{\circ} \mathrm{C}$ for $2 \mathrm{~min} ; 35$ cycles of $98^{\circ} \mathrm{C}$ for $10 \mathrm{sec}, 60^{\circ} \mathrm{C}$ for $30 \mathrm{sec}$, and $72^{\circ} \mathrm{C}$ for $1 \mathrm{~min}$; and 1 cycle of $72^{\circ} \mathrm{C}$ for $5 \mathrm{~min}$.

All analyses were performed using first generation (129B6F1) mice at 2 to 11 months of age, and there were four genotypes: wild type, PS2, Tg2576, and PS2Tg2576. There were approximately equal numbers of male and female mice. All experiments were performed by examiners blinded to the genotypes of the mice. The animals were housed under a 12-hour light/dark cycle and were allowed ad libitum access to food and water. The mice were maintained and studied according to the protocols approved by the Animal Care Committee of the Tokyo Metropolitan Institute of Gerontology.

2.2. Immunohistochemistry. Mouse brains were collected at each time point (2-3, 4-5, 6-7, and 10-11 months of age) after anesthesia and perfusion. The removed brains were split into two hemispheres, and then one was frozen in liquid nitrogen. The other hemisphere was fixed in $4 \%$ paraformaldehyde and embedded in paraffin for the immunohistochemical study. The resultant sections $(5 \mu \mathrm{m})$ were deparaffinized, rehydrated, and washed in phosphate buffered saline (PBS), before being treated briefly with formic acid for $5 \mathrm{~min}$ and washed in running water for $15 \mathrm{~min}$ in the case of $\mathrm{A} \beta$ staining. After incubation for $30 \mathrm{~min}$ in $0.1 \%$ hydrogen peroxide in methanol to prevent endogenous peroxidation, the sections were washed in PBS-T (PBS containing 0.1\% Tween-20) and blocked with 10\% normal goat serum in PBS, before being incubated with an anti-A $\beta$ antibody $(0.5 \mu \mathrm{g} / \mathrm{mL} 82 \mathrm{E} 1, \mathrm{~A} \beta 42$ and $\mathrm{A} \beta 40$, resp., IBL) for 1 hour at room temperature. Then, the sections were incubated with biotinylated secondary antibody for $30 \mathrm{~min}$ at room temperature. Immunoreactivity was visualized using an $\mathrm{ABC}$ Elite kit according to the manufacturer's protocol and the sections were then stained for $5-7 \mathrm{~min}$ with $0.2 \mathrm{mg} / \mathrm{mL}$ diaminobenzidine and $0.1 \%$ hydrogen peroxide in $10 \mathrm{mM}$ Tris- $\mathrm{HCl}$ ( $\mathrm{pH}$ 7.5). The sections were counterstained with Meier's hematoxylin (Wako).

\subsection{Specific Enzyme-Linked Immunosorbent Assay (ELISA)} for $A \beta$. Mouse brain tissue (0.1-0.2 g) was homogenized in 3 volumes $(\mathrm{w} / \mathrm{v})$ of TBS $(50 \mathrm{mM}$ Tris- $\mathrm{HCl}(\mathrm{pH} 7.6)$ containing $150 \mathrm{mM} \mathrm{NaCl}$ supplemented with $0.7 \mathrm{mg} / \mathrm{mL}$ pepstatin A, $1 \mathrm{mM}$ phenylmethylsulfonyl fluoride, and cocktails of protease and phosphatase inhibitors (Complete Mini and PhosSTOP, Roche Diagnostics). The homogenates were centrifuged at 55,000 $\times \mathrm{g}$ for $60 \mathrm{~min}$ at $4^{\circ} \mathrm{C}$ using an Optima TL ultracentrifuge and a TLA-55 rotor (Beckman Coulter) to give the supernatant $(\mathrm{S}-55)$ and pellet $(\mathrm{P}-55)$ fractions. The S-55 fraction was centrifuged at $100,000 \times \mathrm{g}$ for $30 \mathrm{~min}$ at $4^{\circ} \mathrm{C}$, and then the supernatant was collected as a TBSsoluble fraction. The P-55 fraction was then dissolved by sonication in an equal volume $(\mathrm{v} / \mathrm{v})$ of $6 \mathrm{M}$ guanidine- $\mathrm{HCl}$ (Sigma) containing a mixture of protease inhibitors (Roche Diagnostics), followed by centrifugation at $100,000 \times \mathrm{g}$ for $30 \mathrm{~min}$ at $4^{\circ} \mathrm{C}$. The supernatant was diluted in a 12-times volume $(\mathrm{v} / \mathrm{v})$ of TBS to generate a guanidine-soluble fraction. The guanidine-soluble fraction was then centrifuged at $20,400 \times \mathrm{g}$ for $10 \mathrm{~min}$ at $4^{\circ} \mathrm{C}$, and the supernatant was collected as a TBS-insoluble fraction. The total protein concentration of the fractions was determined using the DC protein assay kit (Bio-rad), according to the manufacturer's protocol. The amounts of $A \beta 42$ and $A \beta 40$ in the TBSsoluble and TBS-insoluble fractions were determined using a sandwich EIA kit (No. 27712 for $\mathrm{A} \beta 42$ and 27714 for $\mathrm{A} \beta 40$, IBL), according to the manufacturer's instructions. The no. 27712 kit exclusively detects only human $\mathrm{A} \beta 42$, while the 
no. 27714 kit mainly detects human $\mathrm{A} \beta 40$ but partially reacts with rodent $\mathrm{A} \beta 40$.

2.4. Water Maze. All behavior experiments were performed longitudinally. The water maze pool (Muromachi Kikai), which had a diameter of $120 \mathrm{~cm}$, contained opaque water $(22$ $\left.\pm 2^{\circ} \mathrm{C}\right)$ with a platform $(10 \mathrm{~cm}$ in diameter $)$ that had been submerged $1.5 \mathrm{~cm}$ below the surface. The hidden platform task took 4 days to perform (4 sessions per day, at least 1 hour apart). The platform location remained constant, and the entry points were changed semirandomly between trials. One day after day 4 of the hidden platform task, a 2-minute probe trial was carried out without the platform. The entry point for the probe trials was the quadrant opposite the target quadrant. Performance was monitored with the CompACT VAS/DV video-tracking system (Muromachi Kikai).

2.5. Western Blotting. Mouse brain tissue (approximately $0.2 \mathrm{~g}$ ) was homogenized in 5 volumes (w/v) of RIPA buffer $(25 \mathrm{mM}$ Tris- $\mathrm{HCl}(\mathrm{pH} 7.5)$ containing $150 \mathrm{mM} \mathrm{NaCl}, 1 \%$ NP-40, $1 \%$ sodium deoxycholate, and $0.1 \%$ sodium dodecyl sulfate) supplemented with $0.7 \mathrm{mg} / \mathrm{mL}$ pepstatin $\mathrm{A}, 1 \mathrm{mM}$ phenylmethylsulfonyl fluoride, and a mixture of protease and phosphatase inhibitors (Roche Diagnostics). The protein concentrations of the brain homogenates were determined using the DC protein assay kit, before they were diluted to $1 \mathrm{mg} / \mathrm{mL}$ with EzApply solution (ATTO), according to the manufacturer's instructions.

The proteins ( 10 or $20 \mu \mathrm{g} /$ well) were subjected to a 10\%-20\% gradient Tris-tricine gel (Novex, Invitrogen) and transferred to a PVDF membrane $(0.2 \mu \mathrm{m}$ pore size, Immobilon- $\mathrm{PQ}$, Millipore). Then, the membranes were blocked in TBS-T (TBS containing $0.01 \%$ Tween-20) with $2 \%$ blocking regent (ECL Advance Blocking Agent, GE Healthcare) for 1 hour at room temperature. The membranes were then incubated with anti-APP C-termini antibody $\operatorname{APP}(\mathrm{C})(1 \mu \mathrm{g} / \mathrm{mL}, \mathrm{IBL})$, anti-soluble $\alpha$-cleavage APP fragment (sAPP $\alpha, 5 \mu \mathrm{g} / \mathrm{mL}, \mathrm{IBL})$, anti-soluble $\beta$-cleavage APPswe fragment (sAPP $\beta$ sw, $5 \mu \mathrm{g} / \mathrm{mL}, \mathrm{IBL}$ ), and anti-GAPDH antibody $(0.1 \mu \mathrm{g} / \mathrm{mL}, \mathrm{AbD}$ Serotec) for 1 hour at room temperature, before being washed with TBS-T and treated with the secondary antibody ( 1 hour). The anti-sAPP $\alpha$ and sAPP $\beta$ antibodies exclusively detect only human sAPP $\alpha$ and sAPP $\beta$ sw, respectively, but are not reactive to APP full length. Development was performed with enhanced chemiluminescence reagent (ECL plus, GE Healthcare) and detected using an LAS-3000 Mini (Fujifilm).

2.6. Antibodies. The antibodies used were anti- $\mathrm{A} \beta 42$; $1: 2,000$ (IBL, No. 18582), anti-A $\beta 40 ; 1: 2,000$ (IBL, No. 18580 ), anti-A $\beta(\mathrm{N}) ; 1: 2,000$ (IBL, No. 10323, clone 82E1), anti-APP(C); $1: 100$ (IBL, No. 18961), anti-sAPP $\alpha ; 1: 20$ (IBL, No. 11088, clone 2B3), anti-sAPP $\beta$; $1: 20$ (IBL, No. 10321, clone 6A1) and anti-GAPDH; $1: 3,000$ (AbD Serotec, No. 4699-9555, clone 6G5)

2.7. Statistical Analyses. All data are presented as means \pm s.e.m. The differences among the four groups were analyzed with one-way analysis of variance (ANOVA) followed by Bonferroni's test, and $P$ values of $<.05$ or $<.01$ on the unpaired $T$-test or Welch's test were considered statistically significant.

\section{Results}

3.1. Generation of PS2 (N141I) and Tg2576 Double Transgenic Mice (PS2Tg2576). We crossbred a Tg2576 mouse with PS2 (N141I) mutant mice to generate double transgenic mice. The PS2Tg2576 mutant mice were born at the expected Mendelian ratio in males $(23.0 \%)$ and females $(28.1 \%)$ and grew without morphological abnormalities. Of the male mice, three mutant mice showed a significantly low body weight compared to the wild-type mice (Supplementary Figure 1(a) available online on doi: 10.1155/2011/617974). In the female mice, the PS2Tg2576 and Tg2576 mice exhibited a significantly low body weight compared to the wild-type and PS2 mice (Supplementary Figure 1(b)). However, we failed to detect any differences in food intake (Supplementary Figure 2(a)), drinking water (Supplementary Figure 2(b)), or metabolic parameters (Supplementary Figures 2(c) and 2(d)) among the mutant mice.

3.2. Early Onset of Amyloid Deposition Accompanied by Insoluble A $\beta$ Hyperaccumulation in the Brains of the PS2Tg2576 Mice. To investigate the pathological effect of the familial PS2 (N141I) mutation on Tg2576 mice, amyloid plaques in the brain sections of the PS2Tg2576 mice were immunostained with the 82E1 monoclonal antibody against the Nterminal of $\mathrm{A} \beta$. As shown in Figure 1(a), amyloid depositions were positively detected in the PS2Tg2576 mice at 2-3 months of age. At 4-5 months, significant amyloid accumulations were observed in the hippocampus and the cerebral neocortex of the PS2Tg2576 mice (Figure 1(b)). Interestingly, the levels of typical senile plaques were dramatically increased in the PS2Tg2576 mice at 6-7 months of age (Figure 1(c)); in contrast, no plaques were detected in the brains of the Tg2576 mice at 6-7 months of age (Figure 1(d)). Furthermore, the amyloid plaques also immunoreacted with antibodies against the C-terminus of $\mathrm{A} \beta 42$ (Supplementary Figure 3) or A $\beta 40$ (Supplementary Figure 4), producing the same staining pattern as seen with the 82E1 antibody.

Next, to quantify the amyloid plaques in the neocortex and hippocampus, we measured the number of plaques in the brain sections by densitometric analysis (Table 1 and Figure 2(a)). The mean plaque number of the PS2Tg2576 mice at 2-3 months of age was $17.7 \pm 2.9$, and it had markedly increased at $4-5$ months $(160.3 \pm 4.3)$ and 6-7 months of age ( $645.7 \pm 98.6)$. We failed to count any plaques until 6-7 months of age in the Tg2576, PS2, and wild-type mice (Table 1 and Figure 2(a)). In addition, the numbers of $\mathrm{A} \beta 42$ and $\mathrm{A} \beta 40$ positive-plaques were also increased in the PS2Tg2576 mice with the same pattern (data not shown). These results indicated that PS2Tg2576 mice showed significant deposition of robust senile plaques from a young age (2-3 months of age).

To confirm the results of the immunohistochemical analyses, we measured the concentration of brain $A \beta$ in 


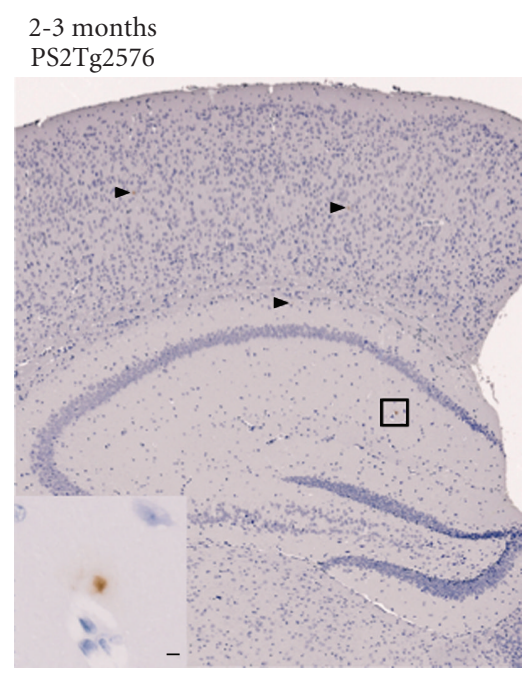

(a)

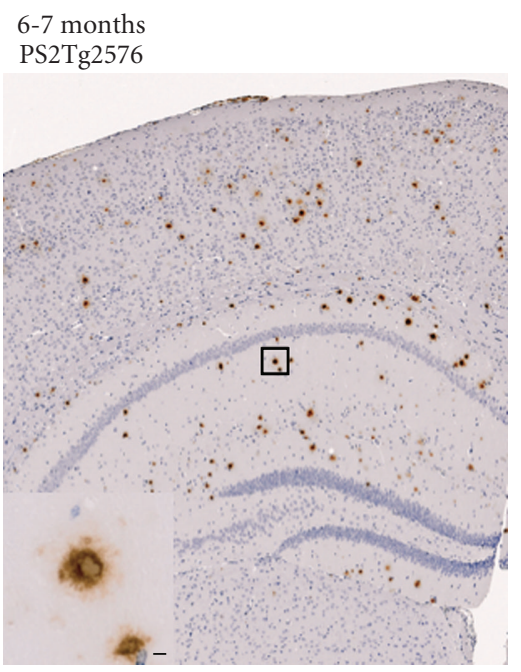

(c)

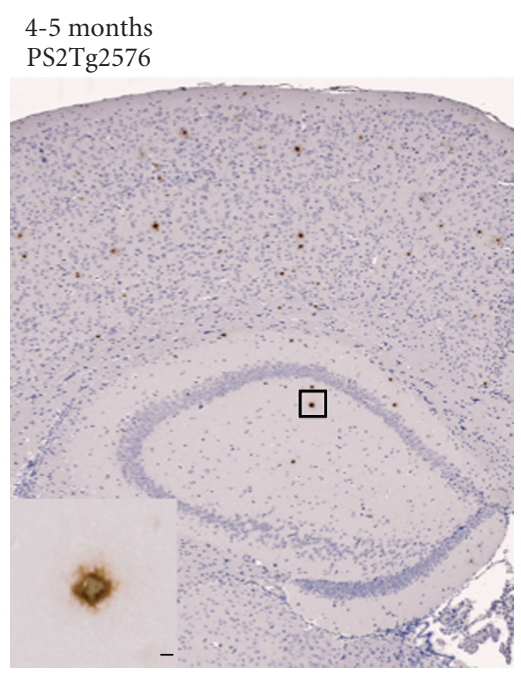

(b)

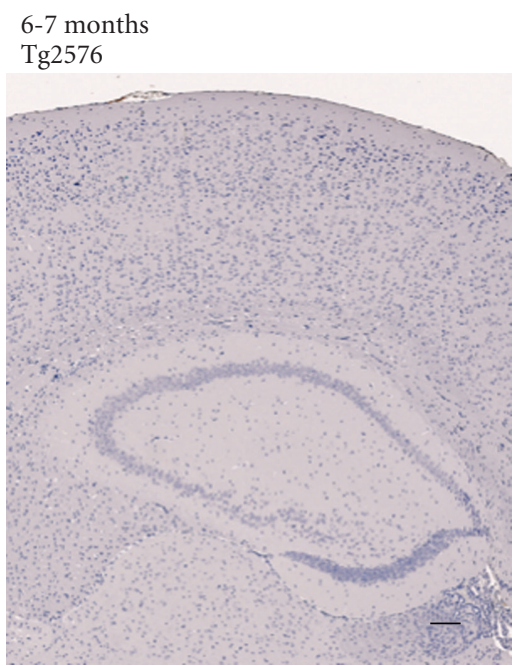

(d)

FIGURE 1: Early accumulation of amyloid deposition in the brains of PS2Tg2576 mice. Amyloid plaques were immunoreacted with the 82E1 monoclonal antibody against the N-terminal of A $\beta$. (a) At 2-3 months of age, typical amyloid plaques were positively detected in PS2Tg2576 mouse brains. (b) At 4-5 months, amyloid depositions were significantly observed in the hippocampus and the cerebral neocortex of the PS2Tg2576 mice. (c) In the 6-7 month-old PS2Tg2576 mice, markedly high levels of typical amyloid plaques were observed. (d) No plaques were detected in the brains of the Tg2576 mice at 6-7-months of age. The insets show a high magnification image of the boxed area. The arrowheads indicate plaques in the PS2Tg2576 mice at 2-3 months of age. The scale bars represent $200 \mu \mathrm{m}$ and $5 \mu \mathrm{m}$ in the main panel and inset, respectively.

the TBS-insoluble fraction by specific ELISA (Table 1 and Figures 2(b) and 2(c)). In agreement with the plaque numbers, the concentrations of $\mathrm{A} \beta 42$ and $\mathrm{A} \beta 40$ in the PS2Tg2576 mice at 2-3 months of age were significantly higher $(4.2 \pm 0.4$ and $2.9 \pm 0.3 \mathrm{ng} / \mathrm{mg}$ protein, resp. $)$ than those in the Tg2576 mice at the same age (Table 1). At 45 months of age, the concentrations of $\mathrm{A} \beta 42$ and $\mathrm{A} \beta 40$ in the PS2Tg2576 mice were dramatically enhanced to $75.2 \pm$ 3.9 and $51.5 \pm 4.0 \mathrm{ng} / \mathrm{mg}$ protein, respectively, (Table 1). At 6-7 months of age, these concentrations in the PS2Tg2576 mice were increased to $411.8 \pm 19.0$ and $380.1 \pm 18.5 \mathrm{ng} / \mathrm{mg}$ protein, respectively (Table 1 ). In contrast, the Tg2576 mice did not show altered levels of insoluble $A \beta$ from $2-3$ to 6-7 months of age. These results indicated that the early accumulation of insoluble $A \beta$ occurs in PS2Tg2576 mice and that the insoluble $\mathrm{A} \beta$ burden was consistent with the results of the immunohistochemical analyses (Figure 2 and Table 1).

In the TBS-soluble fraction, no difference in the levels of $\mathrm{A} \beta 42$ and $\mathrm{A} \beta 40$ was detected in the PS2Tg2576 mice at 2-3 months of age (Table 1). At 4-5 months of age, the concentration of A 342 in the PS2Tg2576 mice was detected to be $2.9 \pm 0.6 \mathrm{pg} / \mathrm{mg}$ protein (Table 1). At 6-7 months of age, the concentrations of $A \beta 42$ and $A \beta 40$ in the PS2Tg2576 mice were significantly higher $(7.1 \pm 0.7$ and $151.4 \pm 11.8 \mathrm{pg} / \mathrm{mg}$ 


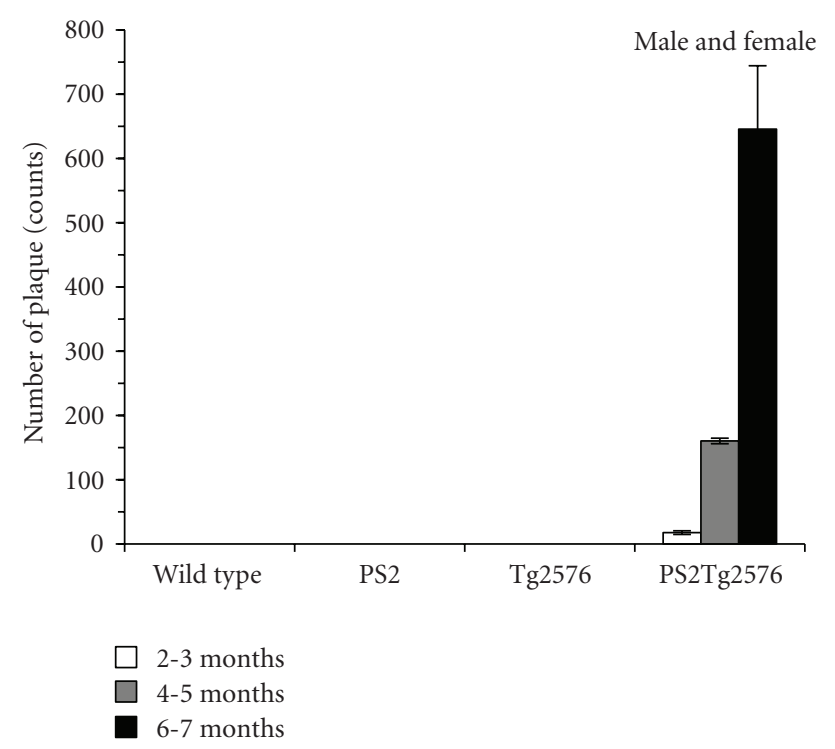

(a)

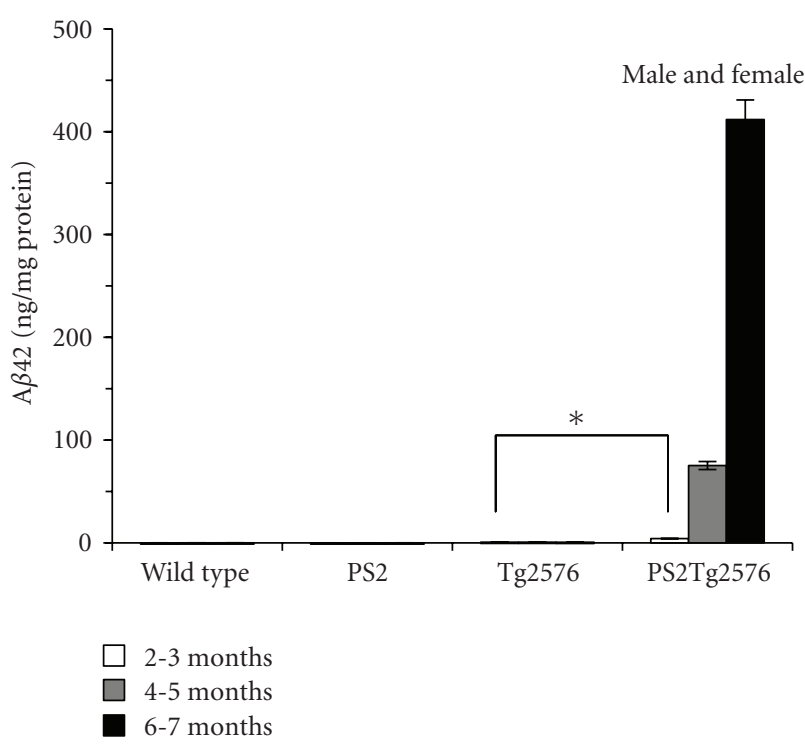

(b)

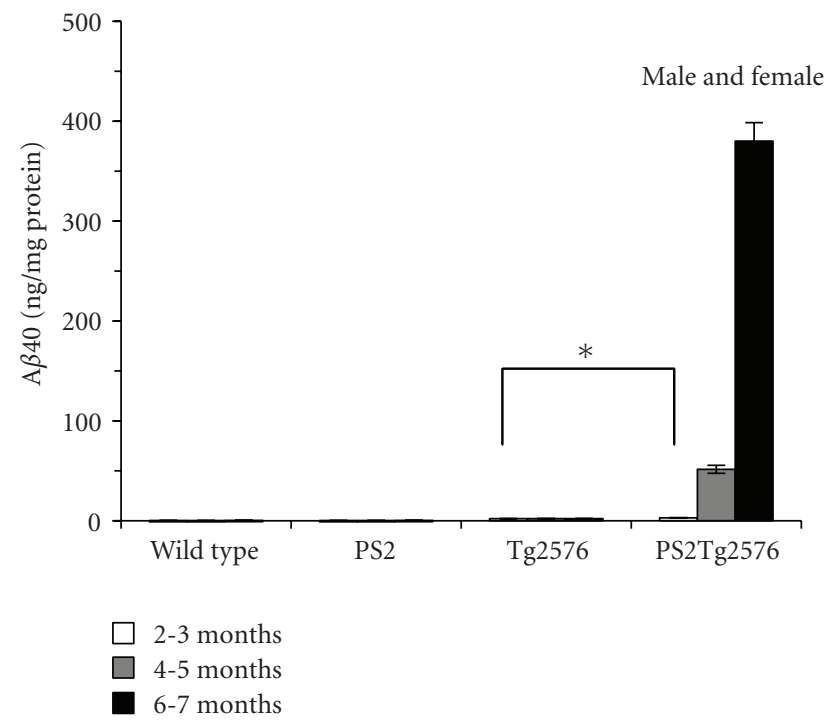

(c)

FIGURE 2: Quantification of cerebral amyloid accumulation in PS2Tg2576 mice. (a) Number of amyloid plaques (counts per cross section of half brain \pm s.e.m) according to 82E1 antibody staining $(n=3)$. ELISA measurement of A $\beta 42(\mathrm{~b})$ and A $\beta 40$ (c) in the TBS-insoluble fraction prepared from whole mouse brains $(n=3-8)$. The values are expressed as mean \pm s.e.m ng per mg of protein. Statistical significance was assessed using the unpaired $T$-test and Welch's test: ${ }^{*} P<.05$ compared with the Tg2576 mice at $2-3$ months of age. No other differences were found.

protein, resp.) than those in the $\operatorname{Tg} 2576$ mice at the same age (Table 1).

\subsection{Acceleration of Spatial Memory Impairment in the Morris} Water Maze. We used the Morris water maze [18] to examine whether the presence of a PS2 mutant transgene leads to the exacerbation of spatial learning and memory dysfunctions in Tg2576 mice. The mouse cohorts with approximately equal numbers of males and females were repeatedly tested at 45 and 6-7 months of age in a longitudinal study. Males and females separately had tendencies similar to the gendermixed results in the behavioral tests (data not shown). At 4-5 months of age, the latency in each group was approximately $30 \mathrm{sec}$ at day 4 (Figure 3(a)). In the probe trial, only the PS2Tg2576 mice demonstrated a significantly low score with regard to the number of crossings over the removed-platform as a narrow range analysis (unpaired $T$-test, $P<.01$ versus Tg2576 mice and $P<.05$ versus wild-type mice, Figures $3(\mathrm{~b})$ and $3(\mathrm{~d})$ ) and the percentage of time spent in the target quadrant as a broad range analysis (unpaired $T$-test, $P<.05$ 


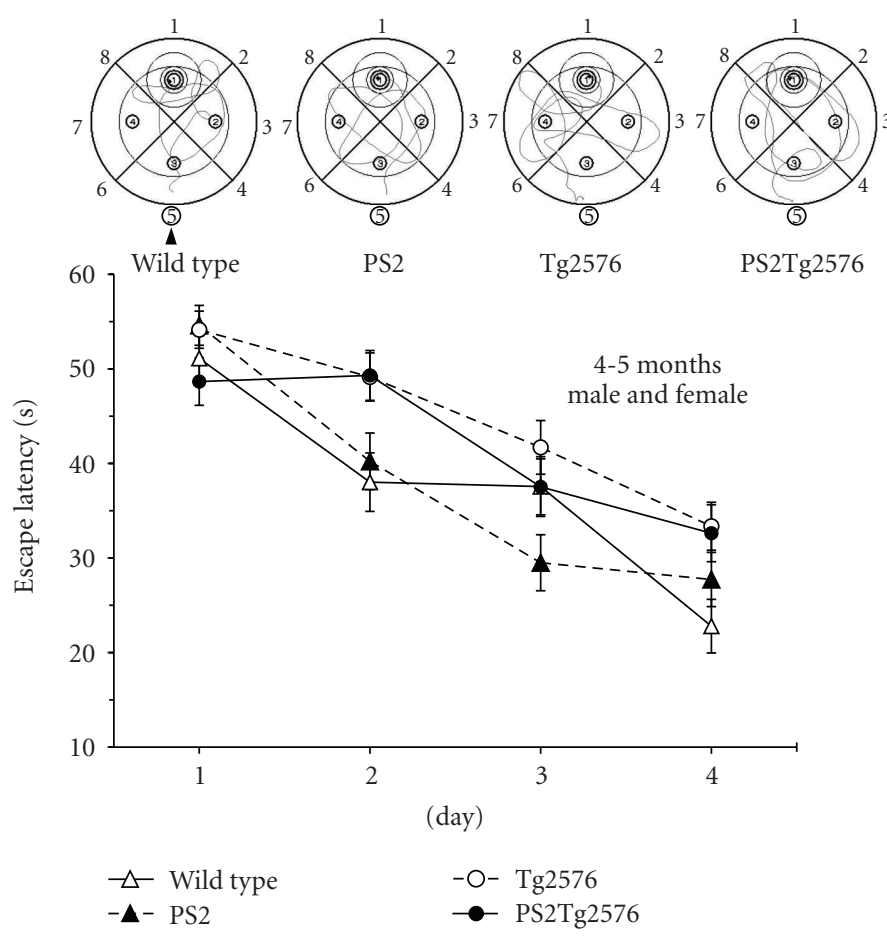

(a)

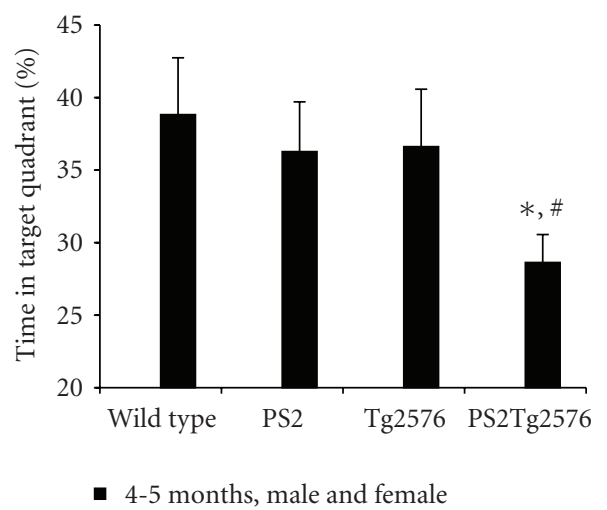

(c)

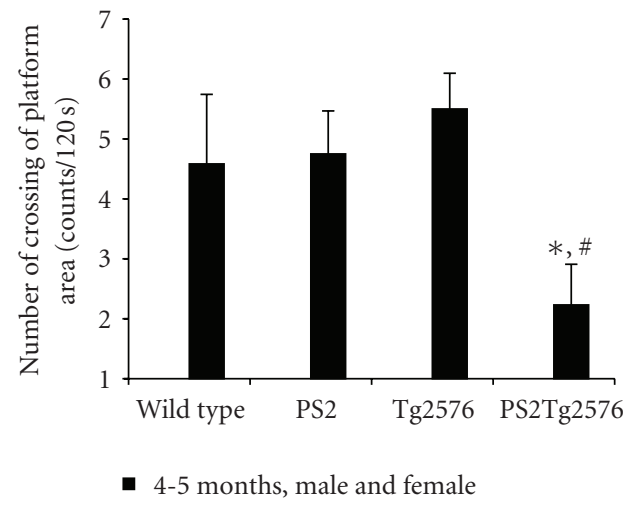

(b)

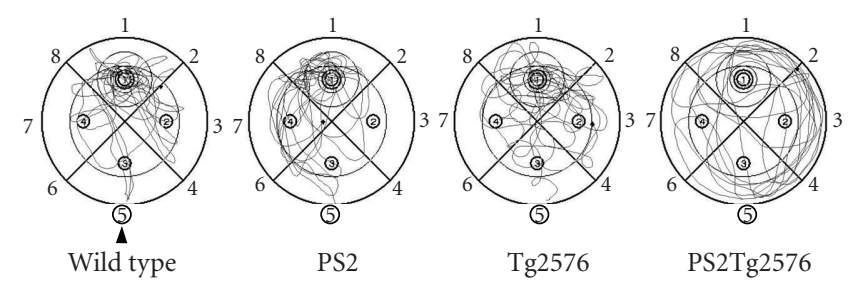

(d)

FIGURE 3: Morris water maze performed at 4-5 months of age of PS2Tg2576 mice. (a) The escape latency of 4-5-month-old mice in the hidden platform trial. Training trials were repeated for 4 days ( 1 minute/trial, 4 trials/day). The graph shows representative swimming paths of individual mice on day 4 of the training phase. (b) The number of crossings of the removed-platform area in the probe test. A probe trial, in which the platform was removed, was performed for 2 minutes on the day after the training trials had finished. (c) Percentage of time spent in the target quadrant during the probe trial. (d) Representative swimming paths of individual mice during the probe test in the training phase. The arrowhead represents the entry point. Values represent the mean \pm s.e.m. $(n=12-24$, female and male mixture). Statistical significance was assessed using the unpaired T-test (c, d): ${ }^{*} P<.05$ compared with the wild-type mice at the same age; ${ }^{\#} P<.05$ compared with the Tg2576 mice at the same age.

versus $\operatorname{Tg} 2576$ mice and $P<.01$ versus wild-type mice, Figures 3(c) and 3(d)).

At 6-7 months of age, only the PS2Tg2576 mice showed a significant typical delay at day 3 and day 4 on the training task (one-way ANOVA and unpaired $T$-test versus wild-type mice, $P<.01$, Figure 4(a)). In contrast, the Tg2576, PS2, and wild-type mice learned to locate the platform during training and quickly achieved the goal (Figure 4(a)). In the probe trial, the PS2Tg2576 mice showed significantly lower scores than the wild-type mice with regard to the number of crossings (unpaired $T$-test, $P<.05$, Figures $4(\mathrm{~b})$ and $4(\mathrm{~d})$ ) and the time spent in the target quadrant (unpaired $T$-test, $P<.01$, Figures 4 (c) and 4(d)). The Tg2576 mice also showed significantly lower scores compared with the wildtype mice with regard to the time spent in the target quadrant (unpaired $T$-test, $P<.05$, Figures $4(\mathrm{c})$ and $4(\mathrm{~d})$ ), indicating 


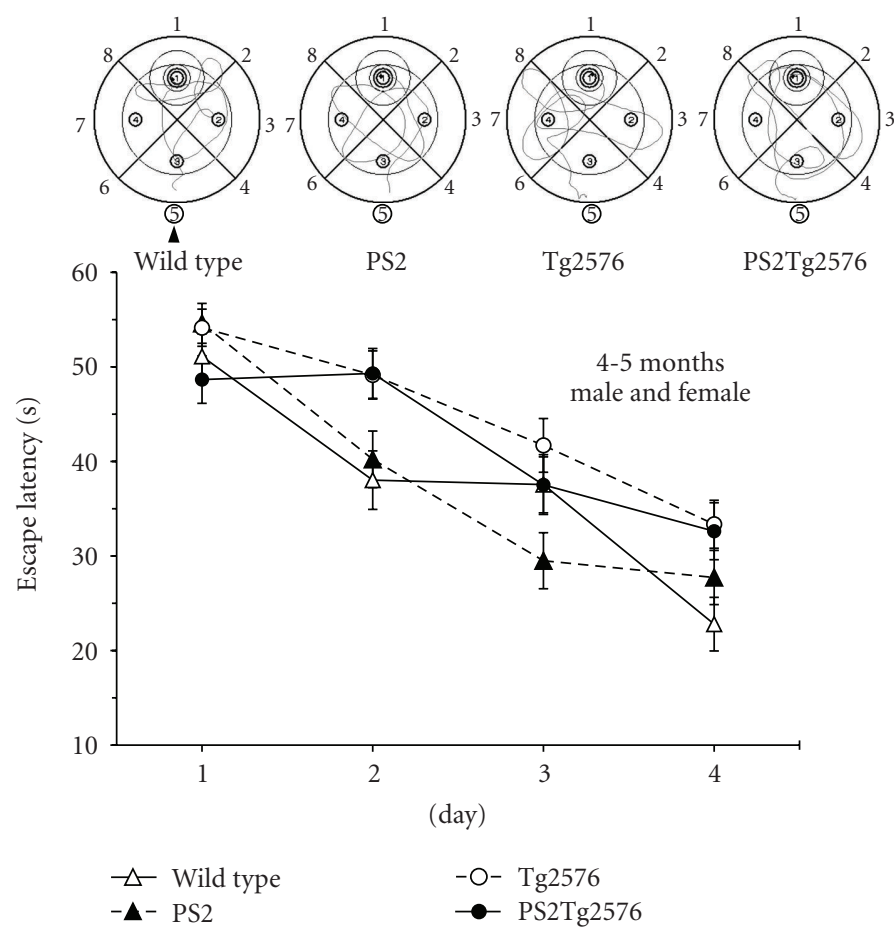

(a)

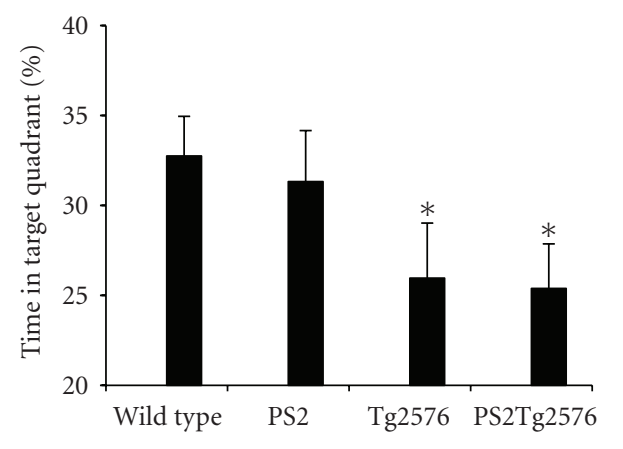

- 6-7 months, male and female

(c)

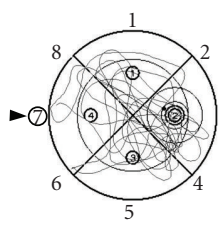

Wild type

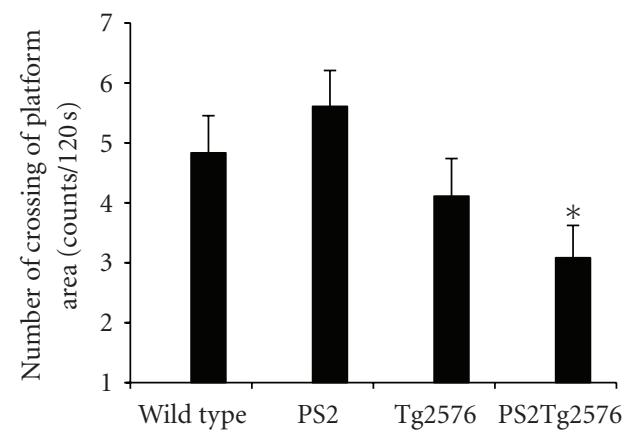

- 6-7 months, male and female

(b)

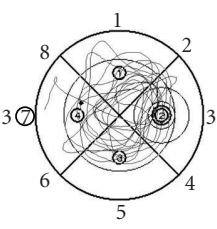

PS2

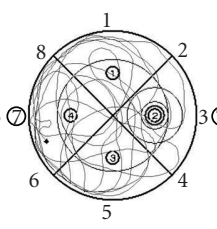

$\operatorname{Tg} 2576$

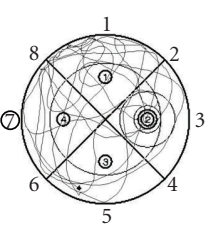

PS2Tg2576

(d)

Figure 4: Morris water maze performed at 6-7-months of age using PS2Tg2576 mice. (a) The escape latency of the 6-7 month-old mice in the hidden platform trial. Training trials were repeated for 4 days (1 minute/trial, 4 trials/day). Only the PS2Tg2576 mice showed significant task errors on days 3 and 4 (using one-way ANOVA, ${ }^{*} P<.05$ ). The graph shows representative swimming paths of individual mice on day 4 of the training phase. (b) The number of crossings of the removed-platform area during the probe test. A probe trial, in which the platform was removed, was performed for 2 minutes on the day after the training trials had finished. (c) Percentage of time spent in the target quadrant during the probe trial. (d) Representative swimming paths of individual mice during the training phase of the probe test. The arrowhead represents the entry point. Values represent the mean \pm s.e.m. $(n=18-24$, approximately equal numbers of male and female mixture). Statistical significance was assessed using the unpaired $T$-test (c, d): ${ }^{*} P<.05$ compared with the wild-type mice at the same age.

that memory impairment progressed in the Tg2576 mice according to age as previously described elsewhere [12]. These results indicated that the PS2 (N141I) mutation significantly accelerates $\mathrm{A} \beta$-dependent spatial learning and memory dysfunction in Tg2576 mice.

Next, we performed other behavioral tests under the placidity home cage, Y maze, elevated plus maze, and open field protocols, because Tg2576 mice showed abnormal activities and behaviors even before $\mathrm{A} \beta$ deposition [9].
Locomotive activity was monitored by infrared sensors in the home cage. At 6-7 months of age, the Tg2576 and PS2Tg2576 mice showed significantly higher activity in the dark phase compared to the PS2 and wild-type mice (Supplementary Figure 5). The same activities were observed in the Tg2576 and PS2Tg2576 mice at 2-3 and 4-5 months of age (data not shown). To investigate cognitive function, we analyzed spontaneous alternation using the Y maze [19]. Our Tg2576 and PS2Tg2576 mice also made fewer alternations in course 
TABLE 1: Characterization of amyloid accumulation in the mouse brain.

\begin{tabular}{|c|c|c|c|c|c|c|}
\hline \multirow{2}{*}{ Genotype } & \multirow{2}{*}{ Age (months) } & \multirow{2}{*}{$\begin{array}{l}\text { Number of } \\
\text { plaques }(n=3) \\
\text { (counts/section) }\end{array}$} & \multicolumn{2}{|c|}{ Insoluble fraction $(n=3-8)$} & \multicolumn{2}{|c|}{ Soluble fraction $(n=3-8)$} \\
\hline & & & $\begin{array}{c}\mathrm{A} \beta 42(\mathrm{ng} / \mathrm{mg} \\
\text { protein })\end{array}$ & $\begin{array}{c}\mathrm{A} \beta 40(\mathrm{ng} / \mathrm{mg} \\
\text { protein })\end{array}$ & $\begin{array}{c}\mathrm{A} \beta 42(\mathrm{pg} / \mathrm{mg} \\
\text { protein })\end{array}$ & $\begin{array}{c}\mathrm{A} \beta 40(\mathrm{pg} / \mathrm{mg} \\
\text { protein })\end{array}$ \\
\hline \multirow{3}{*}{ wild-type } & $2-3$ & ND & ND & $0.2 \pm 0.0$ & ND & $84.2 \pm 4.2$ \\
\hline & $4-5$ & ND & ND & $0.2 \pm 0.0$ & ND & $87.5 \pm 7.1$ \\
\hline & $6-7$ & ND & $\mathrm{ND}$ & $0.3 \pm 0.0$ & $\mathrm{ND}$ & $87.1 \pm 6.3$ \\
\hline \multirow{3}{*}{ PS2 } & $2-3$ & ND & ND & $0.2 \pm 0.0$ & ND & $68.6 \pm 4.7$ \\
\hline & $4-5$ & ND & ND & $0.2 \pm 0.0$ & ND & $93.8 \pm 5.3$ \\
\hline & $6-7$ & ND & $\mathrm{ND}$ & $0.3 \pm 0.0$ & ND & $86.4 \pm 8.3$ \\
\hline \multirow{3}{*}{$\operatorname{Tg} 2576$} & $2-3$ & ND & $0.7 \pm 0.2$ & $2.1 \pm 0.1^{*}$ & ND & $82.5 \pm 23.0$ \\
\hline & $4-5$ & ND & $0.7 \pm 0.1$ & $2.2 \pm 0.1^{*}$ & ND & $83.6 \pm 5.8$ \\
\hline & $6-7$ & $0.0 \pm 0.0$ & $0.6 \pm 0.1$ & $2.2 \pm 0.1^{*}$ & $3.5 \pm 1.0$ & $81.1 \pm 5.1$ \\
\hline \multirow{3}{*}{ PS2Tg2576 } & $2-3$ & $17.7 \pm 2.9$ & $4.2 \pm 0.4^{\#}$ & $2.9 \pm 0.3^{*, \#}$ & ND & $70.7 \pm 5.1$ \\
\hline & $4-5$ & $160.3 \pm 4.3$ & $75.2 \pm 3.9^{\#}$ & $51.5 \pm 4.0^{*, \#}$ & $2.9 \pm 0.6$ & $74.9 \pm 5.0$ \\
\hline & $6-7$ & $645.7 \pm 98.6$ & $411.8 \pm 19.0^{\#}$ & $380.1 \pm 18.5^{*, \#}$ & $7.1 \pm 0.7^{\#}$ & $151.4 \pm 11.8^{*, \#}$ \\
\hline
\end{tabular}

The concentration of cerebral $\mathrm{A} \beta 42$ and $\mathrm{A} \beta 40$ in the TBS-insoluble and soluble fractions was measured with specific ELISA kits. Values represent the mean \pm s.e.m. ND: not detectable. Statistical significance was assessed using the unpaired T-test and Welch's test: $* P<.05$ compared with the wild-type mice at the same age; ${ }^{P} P<.05$ compared with the Tg2576 mice at the same age.

than the PS2 and wild-type mice from 2-3 months of age (Supplementary Figure 6). We also assessed anxiety-based activity using the elevated plus maze task [20]. The elevated plus maze test showed that the $\mathrm{Tg} 2576$ and PS2Tg2576 mice presented with significantly lower scores compared to the PS2 and wild-type mice with regard to the number of entries to open arms as well as the percentage of time spent in open arms (Supplementary Figure 7). Lastly, in the open field exploration [21], we observed no difference among any of the mice (Supplementary Figure 8). Taken together, these results indicated that both PS2Tg2576 and Tg2576 mice showed abnormal behaviors in an $A \beta$-independent manner from 2-3 months of age.

3.4. Western Blot Analysis of $\beta$-Amyloid Precursor Protein $(A P P)$. To investigate whether the PS2 (N141I) mutation enhances the cleavage of APP in Tg2576 mice, we examined the levels of APP processing by Western blotting analyses using antibodies against the C-terminal ends of full-length APP and soluble APP fragments (Figure 5(a)). The low molecular weight bands for the APP C-terminal fragments were consistent with the $13-\mathrm{kDa} \beta$-cleavage fragment $(\beta$ $\mathrm{CTF})$ and the $10-\mathrm{kDa} \alpha$-cleavage fragment $(\alpha-\mathrm{CTF})$ by their apparent molecular mass (Figure 5(b)). These bands were slightly increased in the brain extracts of PS2Tg2576 compared with Tg2576 mice. To confirm the enhancement of $\alpha$ - and $\beta$-cleavages of APP in the PS2Tg2576 mouse brains, we next examined the levels of APP N-terminus fragments (sAPP) by a Western blotting analysis using antisAPP $\alpha$ and $\operatorname{sAPP} \beta$ antibodies. These antibodies specifically recognize the C-terminus of human $\operatorname{sAPP} \alpha$ and $\operatorname{sAPP} \beta$, respectively. The bands corresponding to sAPP $\alpha$ and sAPP $\beta$ were observed in the Tg2576 and PS2Tg2576 mice (Figures 5(c) and 5(d)). Both sAPP bands in the PS2Tg2576 mice were also upregulated compared with those in the Tg2576 mice, indicating that the $\alpha$ - and $\beta$-cleavage activities against APP were upregulated in the PS2Tg2576 mice. In addition, the APP full-length band was slightly enhanced by the PS2 mutation in Tg2576 mice (Figure 5(a)), suggesting that holo-APP proteins were upregulated or stabilized in the PS2Tg2576 mouse brain. These results suggest that the hyperaccumulation of cerebral A $\beta$ in the PS2Tg2576 mice was induced by the modulation of APP processing in the brains of these mice.

3.5. Life Span of PS2Tg2576 Mice. Survival plots for male and female mice of each genotype were produced using Kaplan-Meier survival curves, and statistical significance was calculated using the original method of the log-rank test (Figure 6). In males, the PS2Tg2576 and Tg2576 mice gradually died from day 70 to day 294, but this was not the case for the wild-type or PS2 mice, except for accidental deaths attributed to fighting. In females, the Tg2576 and PS2Tg2576 mice had significantly shortened life spans compared with the wild-type and PS2 mice $(P<.05)$. At 132 days of age, the PS2Tg2576 female mice showed a significant life span extension compared with the Tg2576 mice $(P<.05)$.

\section{Discussion}

In the present study, we showed that a PS2 mutant accelerated $\mathrm{AD}$-like phenotypes such as $\mathrm{A} \beta$ deposition and memory 


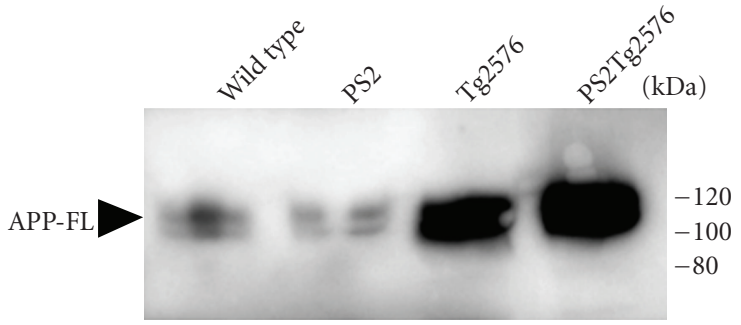

(a)

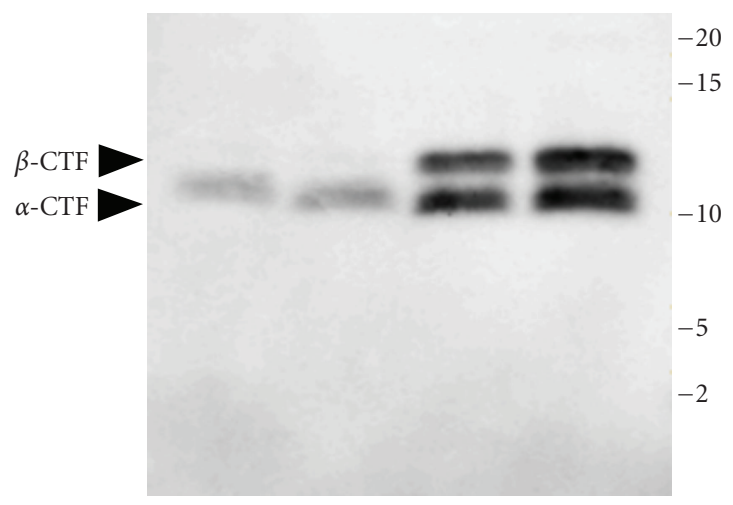

(b)

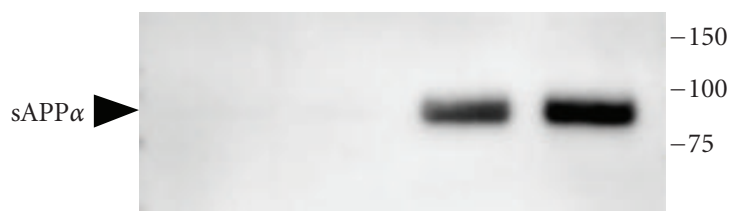

(c)

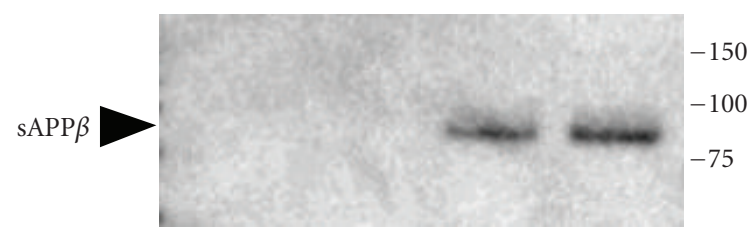

(d)

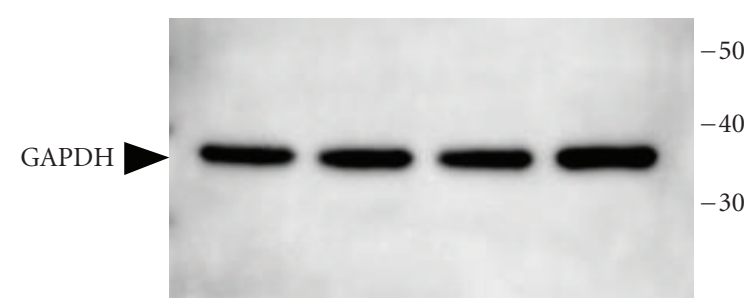

(e)

Figure 5: APP fragments were detected in mouse brains by Western blot analyses. Ten or twenty micrograms of whole brain proteins were prepared from each genotype at 10-11 months of age. (a) Rodent and human APP full-length (APP-FL) and (b) Cterminal fragments $(\beta$ - and $\alpha$-CTF) were detected with the antiAPP C-terminus specific antibody. (c) The $\alpha$-cleavage soluble APP $(\operatorname{sAPP} \alpha)$ band was observed with anti-sAPP $\alpha$ C-terminus specific antibody. (d) The $\beta$-cleavage soluble APP $(\operatorname{sAPP} \beta)$ band appeared with anti-sAPP $\beta$ C-terminus specific antibody. (e) Glyceraldehyde3-phosphate dehydrogenase (GAPDH) was used as an internal standard. impairment. Since the formation of $A \beta 42$ aggregates occurs faster than that of $A \beta 40$ in vitro and increased $A \beta 42$ production accelerates $A \beta$ accumulation in senile plaques [22], insoluble $A \beta 42$ hyperaccumulation in PS2Tg2576 mice (Figure 2(b)) suggests that $A \beta 42$ hyperproduction induces plaque formation in the brain. It has been reported that the PS2 (N141I) mutation upregulates the ratio of $\mathrm{A} \beta 42$ to $\mathrm{A} \beta 40$ by abnormal $\gamma$-secretase activity in cultured cells and transgenic mice $[23,24]$. Unexpectedly, the PS2Tg2576 mice showed enhancement of both $\mathrm{A} \beta 42$ and $\mathrm{A} \beta 40$ including sAPP $\beta$ as well as $\beta$-CTF (Figures 2(b) and 2(c), and Table 1), indicating the modification of APP processing, such as $\gamma$ and $\beta$-cleavage. In addition, the PS2Tg2576 mice showed increased holo-APP protein expression (Figure 5(a)), suggesting that the PS2 mutation upregulates or stabilizes APP proteins, leading to enhancement of APP processing with increased substrate availability. Interestingly, the PS2Tg2576 mice also exhibited the modification of $\alpha$-cleavage of APP, such as sAPP $\alpha$ and $\alpha$-CTF (Figures 5(b) and 5(c)), suggesting that increased substrate availability of APP induced the upregulation of $\alpha$-cleavage. Further studies are needed to clarify the molecular mechanism underlying the $\alpha$ - and $\beta$ cleavage activation and APP upregulation or stabilization induced by the PS2 mutation.

Next, we focused on whether early spatial learning and memory disorders were accelerated in PS2Tg2576 mice. Although errors were generally seen in the water maze task in the Tg2576 mice without amyloid plaques at 6 months of age [12], the PS2 mutation accelerated errorprone exploration by at least 2 months in the Tg2576 mice (Figures 3 and 4). Since amyloid plaque hyper-deposition was observed at 4-5 months of age, we consider that insoluble A $\beta$ hyperaccumulation induced early memory impairment in the PS2Tg2576 mice.

Recently, Saura reported that leukocytes and inflammatory mediators were elevated in the sera of PS conditional double knockout mice on an AD model background, suggesting that genetic inactivation of PS conferred neuronal impairments caused by the inflammatory reaction [25]. De Strooper also reported that FAD-linked PS1 or PS2 mutations, including PS2 (N141I), altered the APP cleavage pattern, leading to an increase of a $\beta$-CTF stubble while there was a decrease in the APP intracellular domain (AICD), Notch intracellular domain (NICD), and ErbB4 intracellular domain (EICD) [26]. Although we failed to detect the AICD band by an anti-APP C-terminal antibody (Figure 5(b)), the depletion of ICDs caused by the PS2 mutation might accelerate neuronal impairments due to the inflammatory response via intracellular signaling through AICD, Notch, or ErbB4 in Tg2576 mice.

Intriguingly, the PS2Tg2576 mice also exhibited earlier onset of AD-like phenotypes compared to those of the PS1Tg2576 [13] or PS2APP [28] double transgenic mice, which were other models of presenilin and APP double transgenic mice. Furthermore, previous reports of PS1Tg2576 and PS2APP mice also suggest that the onset of plaque formation (at 5 and 6 months of age, resp.) was present before the task errors in the water maze occurred at 8 and 15-16 months of age, respectively, (Table 2). Although we cannot explain why 


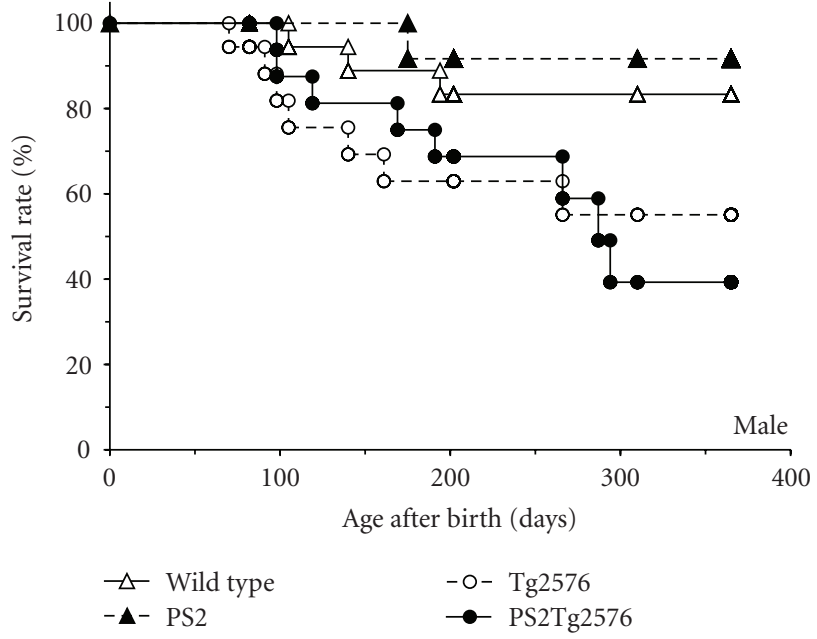

(a)

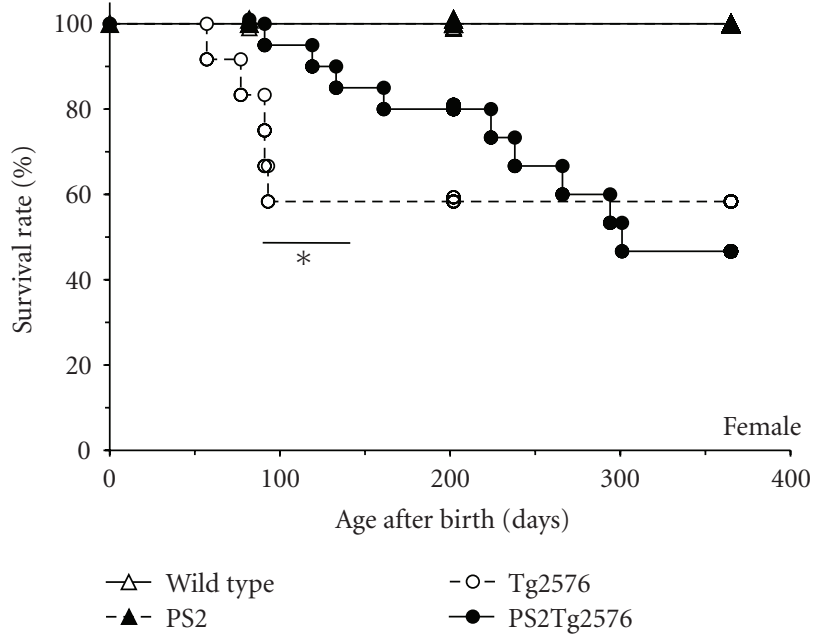

(b)

FIGURE 6: Kaplan-Meier survival curves of the PS2Tg2576 mice. (a) Survival plots for male mice (wild-type $n=20$, PS2 $n=12$, Tg2576 $n=18$, PS2Tg2576 $n=18$ ). (b) Survival plots for female mice (wild-type $n=16, \operatorname{PS} 2 n=21, \operatorname{Tg} 2576 n=12, \operatorname{PS} 2 \operatorname{Tg} 2576 n=21$ ). Statistical significance was assessed using the original method of the log-rank test: ${ }^{*} P<.05$, PS2Tg2576 versus Tg2576 mice at the same age.

TABLE 2: Comparison of AD-like phenotypes in transgenic mouse models.

\begin{tabular}{|c|c|c|c|c|c|}
\hline Mouse model & Genetic background & Transgenes & Plaque onset* & Memory impair" & Ref. \\
\hline $\operatorname{Tg} 2576$ & $\mathrm{FVB} / \mathrm{N}$ & $\begin{array}{l}\text { Prion promoted-APPswe } \\
(\text { K670N, M671L) }\end{array}$ & $7-8$ & 6 & {$[9,12]$} \\
\hline PS1Tg2576 & Unknown & $\begin{array}{l}\text { PDGF } \quad \text { promoted-PS1 } \\
(\mathrm{M} 146 \mathrm{~L}) \times \text { Prion promoted- } \\
\text { APPswe }\end{array}$ & 6 & $15-16$ & {$[13,27]$} \\
\hline PS2APP & B6D2F1 & $\begin{array}{l}\text { Prion promoted-PS2 }(\mathrm{N} 141 \mathrm{I}) \\
\times \text { thyl promoted-APPswe }\end{array}$ & 5 & 8 & {$[28]$} \\
\hline PS2Tg2576 & $\mathrm{B} 6 \times 129 \mathrm{~S} 6$ & 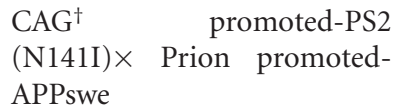 & $2-3$ & $4-5$ & This article \\
\hline
\end{tabular}

${ }^{*}$ Month of age. Previous reported onset of typical amyloid deposition. ${ }^{*}$ Month of age. Previous reports of spatial learning and memory impairment in the Morris water maze. " PDGF, platelet-derived growth factor promoter. ${ }^{\dagger} \mathrm{CAG}$, cytomegalovirus early enhancer coupled with chicken $\beta$-actin promoter.

the PS2Tg2576 mice showed earlier onset of amyloid formation and memory impairment compared to PS1Tg2576 and PS2APP mice, some genetic modifiers might affect $A \beta$ metabolism and memory function in PS2Tg2576 mice.

Interestingly, the levels of insoluble $\mathrm{A} \beta 42$ and $\mathrm{A} \beta 40$ in the brains of the PS2Tg2576 mice at 4-5 months of age were consistent with the values observed in a human FAD patient with the PS2 (N141I) mutation (Table 1). The values of these factors observed in an FAD patient with the PS2 (N141I) mutation were 6.7 and $1.5 \mathrm{ng} / \mathrm{mg}$ wet weight, respectively, in a previous paper by Maarouf et al. [29]. When the concentrations of $A \beta 42$ and $A \beta 40$ in the PS2Tg2576 mice at 4-5 months of age were converted to ng per mg wet weight of mouse brain, they were found to have values of $1.9 \pm 0.1$ and $1.3 \pm 0.1 \mathrm{ng} / \mathrm{mg}$ wet weight, respectively. The insoluble $\mathrm{A} \beta$ burden in the PS2Tg2576 mouse brain was therefore consistent with that found in an FAD case involving a PS2 (N141I) mutation. This data suggests that the AD-like pathology of PS2Tg2576 mice is similar to human
FAD pathology. Recently, noninvasive methods of visualizing amyloid depositions in human brains using positron emission tomography have been developed [30]. Imaging agents against amyloid fibrils such as $\mathrm{N}^{11} \mathrm{C}$ methyl-2-(4'methylaminophenyl)-6-hydroxybenzothiazole $\left({ }^{11} \mathrm{C}-\mathrm{PIB}\right) \mathrm{can}$ be detected in typical AD patients and model mice [31]. By applying this in vivo imaging system to our PS2Tg2576 mice, we would be able to validate interventional protocols such as amyloid-lowering therapies.

\section{Conclusions}

In conclusion, we have demonstrated that PS2Tg2576 mice consistently develop an early-onset and rapidly progressive $\mathrm{AD}$-like cerebral $\beta$-amyloidosis. We have also shown that PS2 mutation induces early insoluble amyloid accumulation and memory impairment in Tg2576 mice, a mouse model of AD. Based on the phenotypic characteristics of the mouse line, we suggest that PS2Tg2576 is a suitable mouse model for 
studying amyloid-lowering therapies and presumably also for validating new target candidates.

\section{Acknowledgments}

This work was supported by Immuno-Biological Laboratories Co, Ltd. The authors thank Mr. Yusuke Ozawa, Mr. Kenji Watanabe, Ms. Miyuki Ito, Mr. Koichi Nakasone, Ms. Nakaba Murata, Mr. Masayoshi Sawada, Mr. Yuta Kamiya, Mr. Shuichi Shibuya, Mr. Shinya Yokoyama, and Dr. Kazuma Murakami from the Tokyo Metropolitan Institute of Gerontology for helpful discussion and technical assistance.

\section{References}

[1] D. J. Selkoe, "Developing preventive therapies for chronic diseases: lessons learned from Alzheimer's disease," Nutrition reviews, vol. 65, part 2, pp. S239-243, 2007.

[2] C. Haass and D. J. Selkoe, "Soluble protein oligomers in neurodegeneration: lessons from the Alzheimer's amyloid $\beta$ peptide," Nature Reviews Molecular Cell Biology, vol. 8, no. 2, pp. 101-112, 2007.

[3] A. Aguzzi and T. O'Connor, "Protein aggregation diseases: pathogenicity and therapeutic perspectives," Nature Reviews Drug Discovery, vol. 9, no. 3, pp. 237-248, 2010.

[4] J. Hardy, "The Alzheimer family of diseases: many etiologies, one pathogenesis?" Proceedings of the National Academy of Sciences of the United States of America, vol. 94, no. 6, pp. 20952097, 1997.

[5] D. L. Price and S. S. Sisodia, "Mutant genes in familial Alzheimer's disease and transgenic models," Annual Review of Neuroscience, vol. 21, pp. 479-505, 1998.

[6] C. Janus and D. Westaway, "Transgenic mouse models of Alzheimer's disease," Physiology and Behavior, vol. 73, no. 5, pp. 873-886, 2001.

[7] G. A. Higgins and H. Jacobsen, "Transgenic mouse models of Alzheimer's disease: phenotype and application," Behavioural Pharmacology, vol. 14, no. 5-6, pp. 419-438, 2003.

[8] D. Games, D. Adams, R. Alessandrini et al., "Alzheimer-type neuropathology in transgenic mice overexpressing V717F $\beta$ amyloid precursor protein," Nature, vol. 373, no. 6514, pp. 523-527, 1995.

[9] K. Hsiao, P. Chapman, S. Nilsen et al., "Correlative memory deficits, $\mathrm{A} \beta$ elevation, and amyloid plaques in transgenic mice," Science, vol. 274, no. 5284, pp. 99-102, 1996.

[10] C. Sturchler-Pierrat, D. Abramowski, M. Duke et al., "Two amyloid precursor protein transgenic mouse models with Alzheimer disease-like pathology," Proceedings of the National Academy of Sciences of the United States of America, vol. 94, no. 24, pp. 13287-13292, 1997.

[11] M. A. Chishti, D. S. Yang, C. Janus et al., "Early-onset Amyloid Deposition and Cognitive Deficits in Transgenic Mice Expressing a Double Mutant Form of Amyloid Precursor Protein 695," Journal of Biological Chemistry, vol. 276, no. 24, pp. 21562-21570, 2001.

[12] M. A. Westerman, D. Cooper-Blacketer, A. Mariash et al., "The relationship between $A \beta$ and memory in the Tg2576 mouse model of Alzheimer's disease," Journal of Neuroscience, vol. 22, no. 5, pp. 1858-1867, 2002.

[13] M. N. Gordon, D. L. King, D. M. Diamond et al., "Correlation between cognitive deficits and $\mathrm{A} \beta$ deposits in transgenic
APP+PS1 mice," Neurobiology of Aging, vol. 22, no. 3, pp. 377$385,2001$.

[14] E. I. Rogaev, R. Sherrington, E. A. Rogaeva et al., "Familial Alzheimer's disease in kindreds with missense mutations in a gene on chromosome 1 related to the Alzheimer's disease type 3 gene," Nature, vol. 376, no. 6543, pp. 775-778, 1995.

[15] G. Marcon, G. Giaccone, C. Cupidi et al., "Neuropathological and clinical phenotype of an Italian Alzheimer family with M239V mutation of presenilin 2 gene," Journal of Neuropathology and Experimental Neurology, vol. 63, no. 3, pp. 199-209, 2004.

[16] N. Sawamura, M. Morishima-Kawashima, H. Waki et al., "Mutant presenilin 2 transgenic mice: a large increase in the levels of $\mathrm{A} \beta 342$ is presumably associated with the low density membrane domain that contains decreased levels of glycerophospholipids and sphingomyelin," Journal of Biological Chemistry, vol. 275, no. 36, pp. 27901-27908, 2000.

[17] F. Oyama, N. Sawamura, K. Kobayashi et al., "Mutant presenilin 2 transgenic mouse: effect on an age-dependent increase of amyloid $\beta$-protein 42 in the brain," Journal of Neurochemistry, vol. 71, no. 1, pp. 313-322, 1998.

[18] R. Morris, "Developments of a water-maze procedure for studying spatial learning in the rat," Journal of Neuroscience Methods, vol. 11, no. 1, pp. 47-60, 1984.

[19] E. Ognibene, S. Middei, S. Daniele et al., "Aspects of spatial memory and behavioral disinhibition in Tg2576 transgenic mice as a model of Alzheimer's disease," Behavioural Brain Research, vol. 156, no. 2, pp. 225-232, 2005.

[20] M. Tabuchi, T. Yamaguchi, S. Iizuka, S. Imamura, Y. Ikarashi, and Y. Kase, "Ameliorative effects of yokukansan, a traditional Japanese medicine, on learning and non-cognitive disturbances in the Tg2576 mouse model of Alzheimer's disease," Journal of Ethnopharmacology, vol. 122, no. 1, pp. 157-162, 2009.

[21] N. R. Rustay, E. A. Cronin, P. Curzon et al., "Mice expressing the Swedish APP mutation on a 129 genetic background demonstrate consistent behavioral deficits and pathological markers of Alzheimer's disease," Brain Research, vol. 1311, pp. 136-147, 2010.

[22] T. Iwatsubo, D. M. A. Mann, A. Odaka, N. Suzuki, and Y. Ihara, "Amyloid $\beta$ protein $(\mathrm{A} \beta)$ deposition: $\mathrm{A} \beta 42(43)$ precedes $\mathrm{A} \beta 40$ in Down syndrome," Annals of Neurology, vol. 37, no. 3, pp. 294-299, 1995.

[23] T. Tomita, K. Maruyama, T. C. Saido et al., "The presenilin 2 mutation (N141I) linked to familial Alzheimer disease (Volga German families) increases the secretion of amyloid $\beta$ protein ending at the 42nd (or 43rd) residue," Proceedings of the National Academy of Sciences of the United States of America, vol. 94, no. 5, pp. 2025-2030, 1997.

[24] R. M. Page, K. Baumann, M. Tomioka et al., "Generation of $\mathrm{A} \beta 38$ and $\mathrm{A} \beta 42$ is independently and differentially affected by familial Alzheimer disease-associated presenilin mutations and $\gamma$-secretase modulation," Journal of Biological Chemistry, vol. 283, no. 2, pp. 677-683, 2008.

[25] C. A. Saura, "Presenilin/gamma-secretase and inflammation," Frontiers in Aging Neuroscience, vol. 2, p. 16, 2010.

[26] B. De Strooper, "Loss-of-function presenilin mutations in Alzheimer disease. Talking Point on the role of presenilin mutations in Alzheimer disease," EMBO Reports, vol. 8, no. 2, pp. 141-146, 2007.

[27] K. Duff, C. Eckman, C. Zehr et al., "Increased amyloid$\beta 42(43)$ in brains of mice expressing mutant presenilin 1," Nature, vol. 383, no. 6602, pp. 710-713, 1996.

[28] J. G. Richards, G. A. Higgins, A. M. Ouagazzal et al., "PS2APP 
transgenic mice, coexpressing hPS2mut and hAPPswe, show age-related cognitive deficits associated with discrete brain amyloid deposition and inflammation," Journal of Neuroscience, vol. 23, no. 26, pp. 8989-9003, 2003.

[29] C. L. Maarouf, I. D. Daugs, S. Spina et al., "Histopathological and molecular heterogeneity among individuals with dementia associated with Presenilin mutations," Molecular Neurodegeneration, vol. 3, no. 1, article 20, 2008.

[30] J. Maeda, B. Ji, T. Irie et al., "Longitudinal, quantitative assessment of amyloid, neuroinflammation, and anti-amyloid treatment in a living mouse model of Alzheimer's disease enabled by positron emission tomography," Journal of Neuroscience, vol. 27, no. 41, pp. 10957-10968, 2007.

[31] J. C. Price, W. E. Klunk, B. J. Lopresti et al., "Kinetic modeling of amyloid binding in humans using PET imaging and Pittsburgh Compound-B," Journal of Cerebral Blood Flow and Metabolism, vol. 25, no. 11, pp. 1528-1547, 2005. 


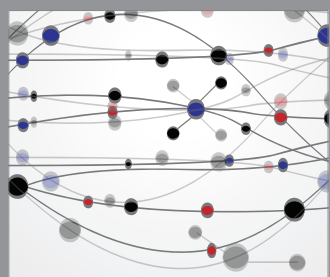

The Scientific World Journal
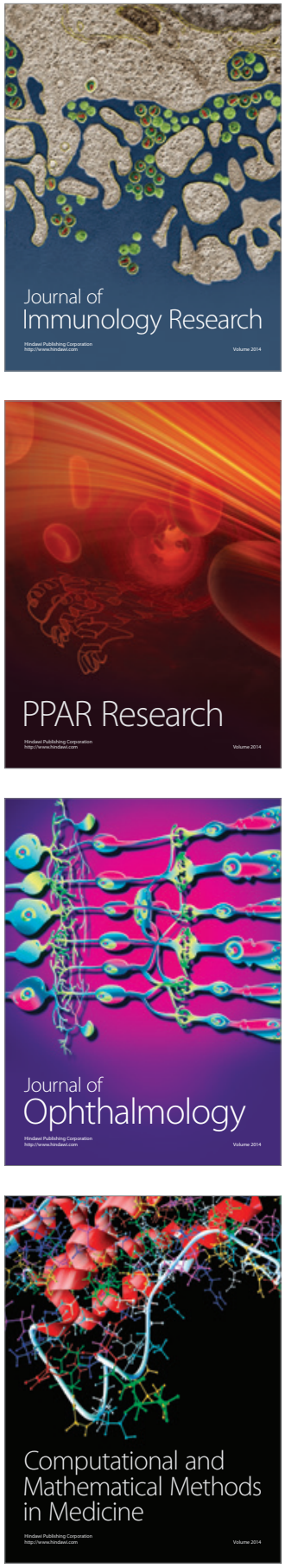

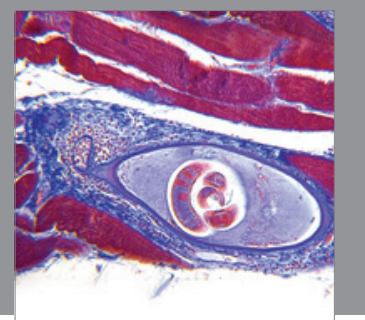

Gastroenterology

Research and Practice
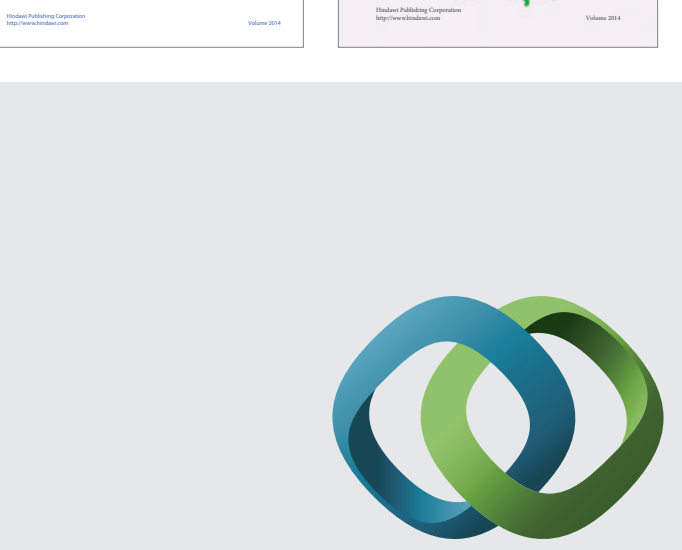

\section{Hindawi}

Submit your manuscripts at

http://www.hindawi.com
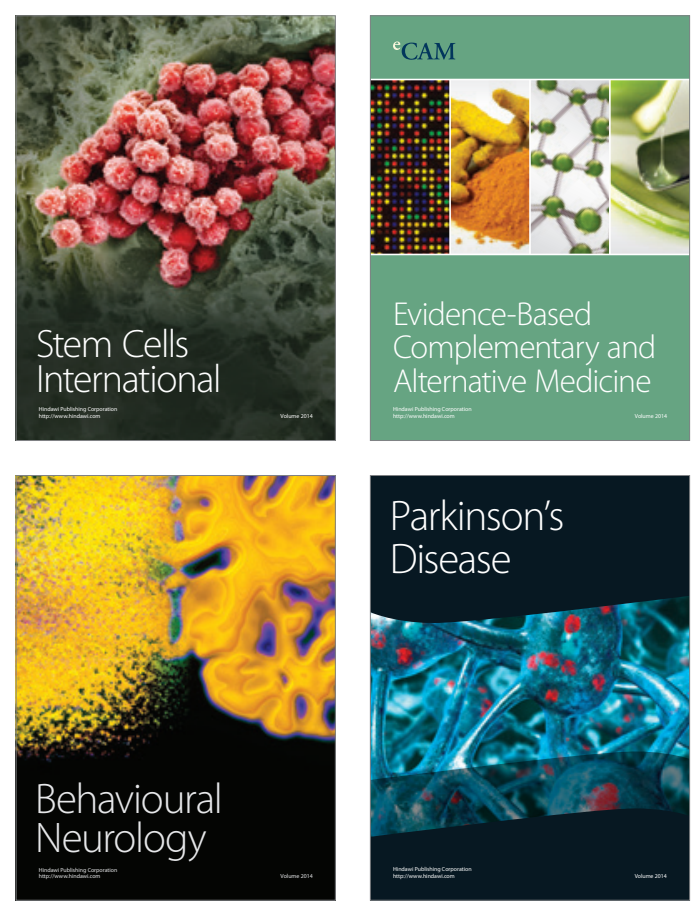

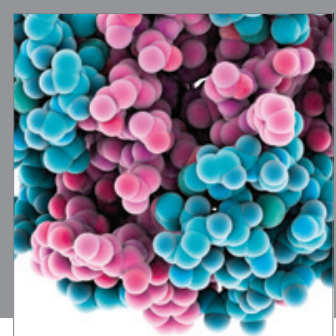

Journal of
Diabetes Research

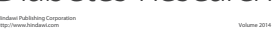

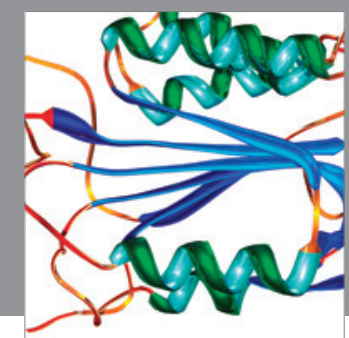

Disease Markers
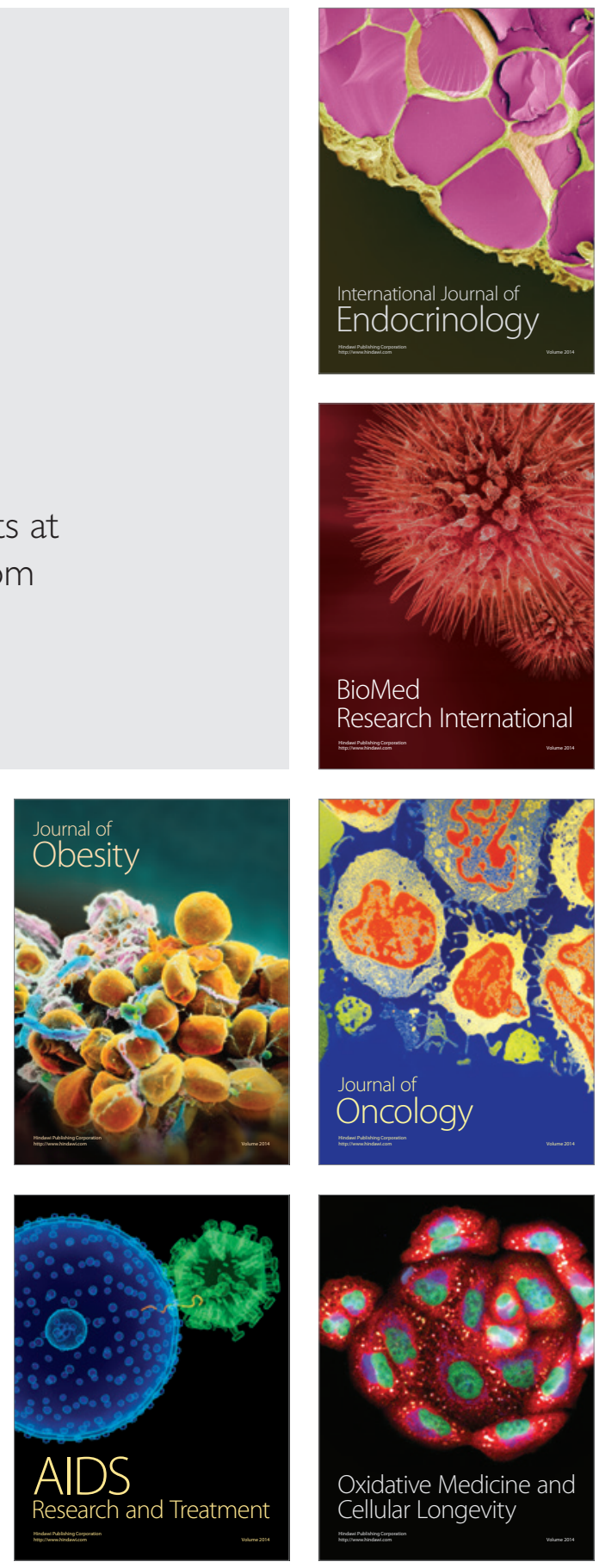